\title{
A Novel Inhibitor of Hypertonicity-Induced Cation Channels in HeLa Cells
}

\author{
Tomohiro NUMATA ${ }^{1}$, Frank WEHNER ${ }^{2}$, and Yasunobu OKADA ${ }^{1}$ \\ ${ }^{1}$ Department of Cell Physiology, National Institute for Physiological Sciences, Okazaki, Japan; and 2Department of Systemic Cell \\ Biology, Max-Planck-Institute of Molecular Physiology, Dortmund, Germany
}

\begin{abstract}
Despite the paramount significance of hypertonicityinduced cation channels (HICCs) in cell proliferation and apoptosis, a detailed analysis of these processes is hindered by the very limited number of HICC blockers available. Here, 2-aminoethoxydiphenyl borate (2-APB) is introduced as a novel and ef-
\end{abstract}

fective inhibitor of the HICC in HeLa cells. Its efficiency is defined with reference to flufenamic acid (as the most potent blocker so far), both, in whole-cell patch-clamp recordings and in measurements of cell volume regulation.

Key words: HeLa cells, cell volume regulation, cation channel, flufenamic acid, 2-aminoethoxydiphenyl borate.

$\mathrm{I}_{\mathrm{t}}$ has become increasingly evident, in recent years, that cell volume and its regulatory mechanisms are of paramount importance for, both, cell proliferation and apoptosis, the programmed cell death as the mechanism of tumour defence [1-3]. Hypertonicity-induced cation channels (HICCs), for instance, have proven to be a most effective mechanism of $\mathrm{Na}^{+}$import in the regulatory volume increase (RVI) of a shrunken cell [3-5] and, also, to facilitate proliferation and significantly interfere with the initiation of apoptosis [6]. Despite the interesting role that HICCs appear to play in these processes, a detailed analysis of their interrelation is hindered by the very limited number of channel inhibitors available. In HeLa cells, for example, HICC currents are effectively blocked by the anti-inflammatory drug flufenamic acid and by the lanthanide $\mathrm{Gd}^{3+}[6,7]$. However, their concentration-response relations have not yet been obtained. Also, the latter is, unfortunately, known to quantitatively complex with several physiologically relevant anions, such as $\mathrm{HCO}_{3}^{-}$, $\mathrm{SO}_{4}{ }^{2-}$ and $\mathrm{PO}_{4}{ }^{2-}$ [8], the omission of which will significantly reduce the amount of cell proliferation per se. In the present report, 2-aminoethoxydiphenyl borate (2APB) is therefore introduced as a novel and efficient blocker of the HICC in HeLa cells, and its effects on channel activation as well as on the process of RVI are defined together and with reference to the established inhibitor flufenamic acid.

\section{Methods}

Experiments were performed on HeLa cells (derived from human cervix carcinoma). The cells were grown as monolayers in minimum essential medium supplemented with $10 \%$ fetal bovine serum, $100 \mu \mathrm{g} / \mathrm{ml}$ streptomycin and $40 \mathrm{IU} / \mathrm{ml}$ penicillin, under $95 \%$ air $-5 \% \mathrm{CO}_{2}$ at $37^{\circ} \mathrm{C}$. For the experiments, cells were detached from the culture flasks with a jet of culture medium and then kept in suspension for 30 to $120 \mathrm{~min}$.

Membrane currents were recorded in the fast wholecell mode of the patch-clamp technique, as was described in detail previously $[6,7]$. The bath solution $(\mathrm{pH} 7.5)$ contained (in $\mathrm{mM}$ ): $\mathrm{NaCl}, 94$; Na-gluconate, $6 ; \mathrm{MgCl}_{2}, 1$; $\mathrm{CaCl}_{2}$, 2; TEA-Cl, 2; HEPES, 10; glucose, 10. Osmolality was adjusted to 310 (isotonic) and $400 \mathrm{mosmol} / \mathrm{kg}-\mathrm{H}_{2} \mathrm{O}$ (hypertonic) by the addition of mannitol under osmometric control (OM802; Vogel, Giessen, Germany). The pipette solution $\left(\mathrm{pH} \mathrm{7.3,300} \mathrm{mosmol} / \mathrm{kg}-\mathrm{H}_{2} \mathrm{O}\right)$ contained: $\mathrm{NaCl}, 26$; Na-gluconate, $69 ; \mathrm{MgCl}_{2}$, 1; TEA-Cl, 2; $\mathrm{Na}_{2}-$ ATP, 2; $\mathrm{Na}_{2}$-GTP, 0.5; HEPES, 10; EGTA, 1. With these ion gradients, the equilibrium potentials for $\mathrm{Na}^{+}$and $\mathrm{Cl}^{-}$ as the only permeant ions are set at 0 and $-30 \mathrm{mV}$, respectively. Voltage ramps from -80 to $+20 \mathrm{mV}$ and of $1 \mathrm{~s}$ duration were applied every $10 \mathrm{~s}$; holding voltage $\left(\mathrm{V}_{\mathrm{h}}\right)$ was $-30 \mathrm{mV}$.

The changes of HeLa cell volume were quantified by means of electronic cell sizing on a Coulter-type analyzer (CDA-500; Sysmex, Kobe, Japan), as previously described [7]. Experimental solutions contained (in $\mathrm{mM}$ ): $\mathrm{NaCl}, 95 ; \mathrm{KCl}, 4.5 ; \mathrm{MgCl}_{2}, 1 ; \mathrm{CaCl}_{2}, 1 ; \mathrm{NaHCO}_{3}, 10$; HEPES, 5. Osmolality was adjusted to 300 (isotonic) and $500 \mathrm{mosmol} / \mathrm{kg}-\mathrm{H}_{2} \mathrm{O}$ (hypertonic).

Measurements were performed at room temperature. All reagents were purchased from Sigma Aldrich (Tokyo,

Received on Mar 29, 2007; accepted on Jun 26, 2007; released online on Jun 28, 2007; doi:10.2170/physiolsci.SC003007 Correspondence should be addressed to: Frank Wehner, Department of Systemic Cell Biology, Max-Planck-Institute of Molecular Physiology, Otto-Hahn-Strasse 11, Dortmund 44227, Germany. Phone: +49-231-133-2225, Fax: +49-231-133-2699, E-mail: frank.wehner@mpi-dortmund.mpg.de 
Japan). Data are presented as mean values \pm SEM with $n$ denoting the number of observations. Student's $t$-tests for paired and unpaired data were used as appropriate, and $P$ $<0.05$ was considered significant.

\section{Results and discussion}

Whenever the RVI of a given system was studied in a quantitative fashion, HICCs have proven to function as the main mechanism of this process [3-5]. This also holds for HeLa cells where the relative contribution of the HICC and of NHE1 to hypertonic volume control could recently be shown to equal approximately 2:1 (and with no role of NKCC1 in RVI detectable, at all) [7]. In the same study, SKF-96365, a known inhibitor of the gene family of "transient receptor potential (TRP)" types of channels, exhibited a significant reduction of HICC currents to some $70 \%$ of control when applied at $100 \mu \mathrm{M}$. On the one hand, this was interpreted in terms of a possible molecular correlation between the HICC and some type of TRP channel [7]. With respect to the present study, we were hypothesizing
A HYPER

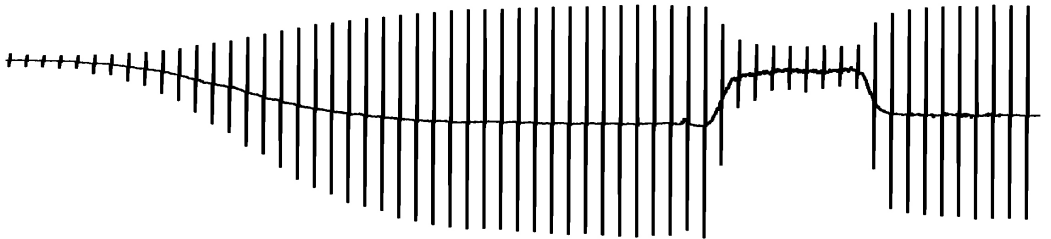

B
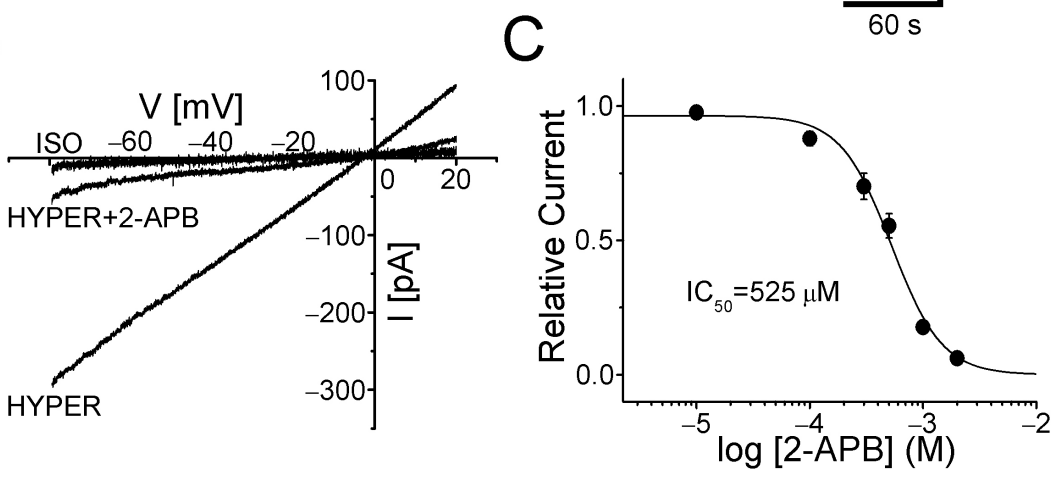

Fig. 1. Effects of 2-aminoethoxydiphenyl borate (2-APB) on HICC currents in HeLa cells. A: Typical whole-cell recording at $\mathrm{E}_{\mathrm{Cl}}$ $=-30 \mathrm{mV}$. Vertical deflections are caused by $1 \mathrm{~s}$ voltage ramps from -80 to $+20 \mathrm{mV}$ that were applied every $10 \mathrm{~s}$. For the times indicated, osmolality was increased from 310 to $400 \mathrm{mosmol} / \mathrm{kg}-\mathrm{H}_{2} \mathrm{O}$ (open bar) and $1 \mathrm{mM}$ 2-APB was added to the superfusate (filled bar). Note, the pronounced increase of $\mathrm{Na}^{+}$current and membrane conductance upon hypertonic stress (HYPER), both being effectively blocked by 2-APB. B: Current-voltage relations (determined during single voltage ramps) under isotonic conditions (ISO), at maximal HICC activation (HYPER) and following the addition of 2APB (HYPER+2-APB). C: Dependence of HICC currents on the concentration of 2APB. Experimental data were fitted on the basis of the Hill equation ( $n=5$ to 10 , for each data point).
A
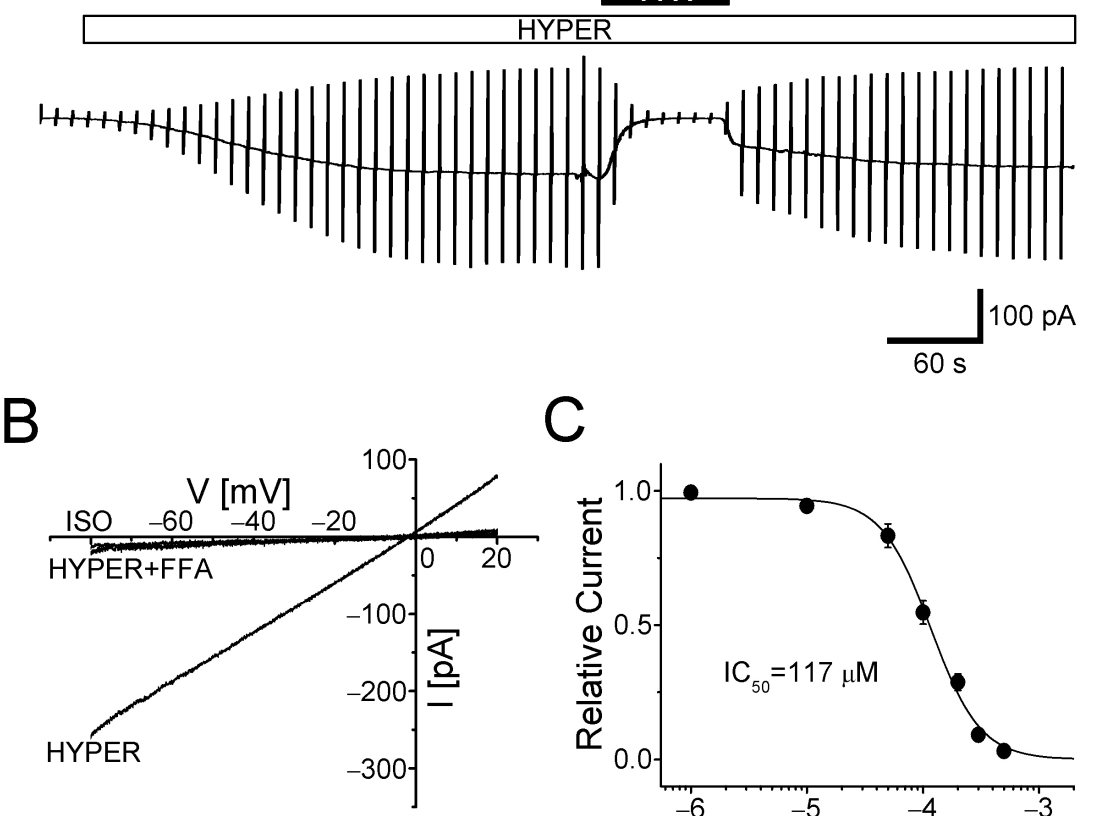

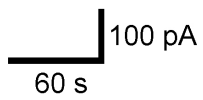

C

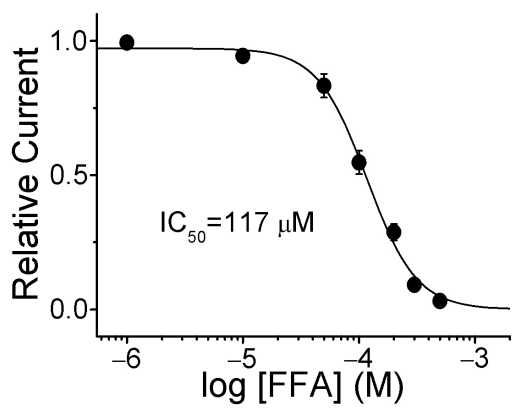

Fig. 2. Effects of flufenamic acid (FFA) on HICC currents. A: Representative experiment with $300 \mu \mathrm{M}$ of the compound. B: Current-voltage relations under isotonic conditions (ISO), at maximal HICC activation (HYPER) and following the addition of flufenamic acid (HYPER+FFA). C: Concentration dependence of HICC currents on flufenamic acid. ( $n=5$ to 10 , for each data point). 
A
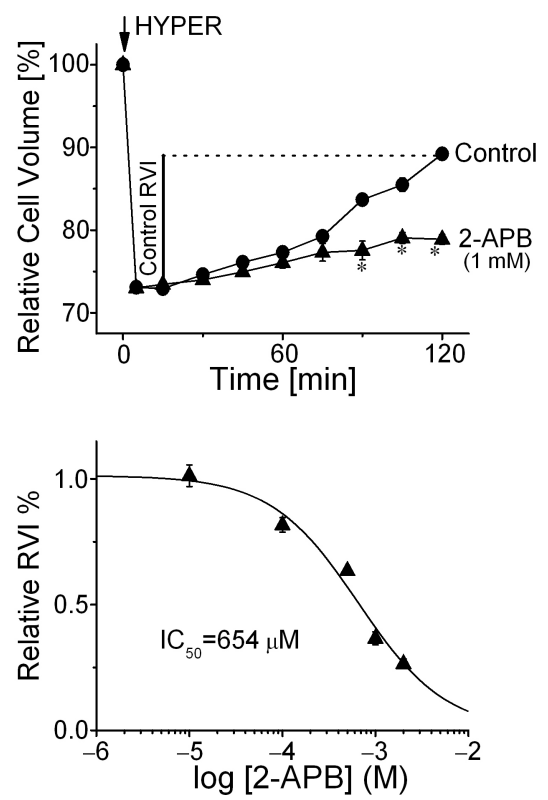

B
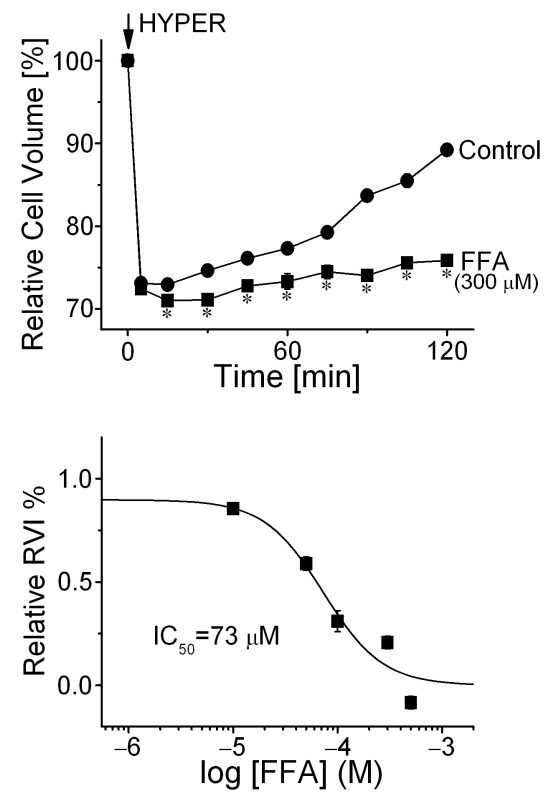

Fig. 3. Effects of 2-APB (A) and FFA (B) on HeLa cell RVI analyzed by means of electronic cell sizing. At time zero, osmolality was increased from 300 to 500 mos$\mathrm{mol} / \mathrm{kg}-\mathrm{H}_{2} \mathrm{O}$ (arrow). RVI was computed with reference to the maximal amount of cell shrinkage observed at $15 \mathrm{~min}$ of hypertonic stress. Experiments were performed under control conditions and in the presence of various concentrations of 2-APB and FFA, as indicated. $n=5$ to 10 for each data point.

that, on the other hand, some further inhibitor of TRP channels may possibly function as a potent blocker of the HICC in HeLa cells.

2-Aminoethoxydiphenyl borate (2-APB) was originally proposed as a membrane permeable inhibitor of IP3 receptors [9]. In recent years, however, it became rather obvious that $2-\mathrm{APB}$ is an effective blocker (and in some cases an activator) of a variety of TRP channels, as well. These include the "canonical" TRPC1 [10], TRPC3 [11], TRPC5 and C6 [12], the "vanilloid" TRPV1 to V3 [13, 14] and TRPV6 [15], as well as the "melastatin" TRPM6 and M7 [16], and TRPM8 [14]. Interestingly, in these studies, 2-APB was quite typically applied in the range of $10 \mu \mathrm{M}$ to $1 \mathrm{mM}$.

Changing extracellular osmolality from 310 to 400 mosmol $/ \mathrm{kg}-\mathrm{H}_{2} \mathrm{O}$, led to an increase of $\mathrm{Na}^{+}$currents (determined at $\mathrm{V}_{\mathrm{h}}=\mathrm{E}_{\mathrm{Cl}}=-30 \mathrm{mV}$ ) in HeLa cells from $-0.32 \pm$ 0.07 to $-4.03 \pm 0.52 \mathrm{pA} / \mathrm{pF}$, i.e. by $-3.71 \pm 0.53 \mathrm{pA} / \mathrm{pF}(n$ $=10, P<0.001$; see Fig. 1, A and B, and Fig. 2, A and B). Application of $1 \mathrm{mM} 2$-APB reversibly reduced HICC currents by $82.3 \pm 1.2 \%(n=9, P<0.001$; Fig. $1, \mathrm{~A}$ and B). The effect of 2-APB on HICC currents exhibited a clear concentration dependence from which an $\mathrm{IC}_{50}$ value of $525 \mu \mathrm{M}$ could be derived (Fig. 1C).

As exemplified in Fig. 2 (A, B), $300 \mu \mathrm{M}$ flufenamic acid (FFA) reduced HICC currents by $90.1 \pm 1.9 \%(n=$ 10, $P<0.001$; Fig. 2, A and B). As with 2-APB, the current inhibition by flufenamic acid was completely reversible. From the concentration dependence of the effect, an $\mathrm{IC}_{50}$ value of $117 \mu \mathrm{M}$ could be determined (Fig. 2C).

Then, the effects of 2-APB and FFA on the RVI of HeLa cells were determined. As depicted in Fig. 3, increasing osmolality from 300 to $500 \mathrm{mosmol} / \mathrm{kg}-\mathrm{H}_{2} \mathrm{O}$ led to an initial shrinkage of cells to $73.1 \pm 0.3 \%$ of the refer- ence value in the control experiments $(n=10, P<0.001)$. Thereafter cell volume was increasing again to $89.2 \pm$ $0.6 \%$, at 120 min of hypertonic stress. Referred to the initial amount of cell shrinkage, this is equivalent to an actual RVI value of $59.8 \pm 2.4 \%(P<0.001)$. In the presence of $1 \mathrm{mM} 2-\mathrm{APB}$ and $300 \mu \mathrm{M}$ FFA, RVI was reduced to $21.9 \pm$ $1.5 \%$ and $12.8 \pm 1.8 \%$, respectively $(n=10, P<0.001$ with reference to the control recordings, each; Fig. 3, A and $\mathrm{B}$ ). From the dose-response curves, $\mathrm{IC}_{50}$ values of 654 $\mu \mathrm{M}$ and $73 \mu \mathrm{M}$ were obtained for both compounds. These results prove the effective blockage of the HICC by 2 APB as well as FFA on the physiological basis of cell volume regulation. The pronounced similarity of the $\mathrm{IC}_{50}$ values obtained with patch-clamp and electronic cell-sizing experiments for both substances also strongly supports the paramount role of the HICC in the RVI process. Furthermore, the observed similarity of the concentration dependencies determined supports the notion of a sustained activation of the HICC during the period of hypertonic exposure.

In conclusion, 2-APB is a novel, potent and reversible blocker of the HICC in HeLa cells that will facilitate the future defined analysis of the interplay between cell volume regulation and proliferation vs. apoptosis. In addition, for the first time, the concentration dependency of the effects of flufenamic acid on HICC currents was quantified. And last but-not-least, the block of HICC currents by 2-APB as an inhibitor of TRP channels provides further evidence for a possible molecular correlation between both types of channels.

This work was supported by Grants-in-Aid for Scientific Research from the Ministry of Education, Culture, Sports, Science and Technology of Japan (MEXT) and from the Japan Society for the Promotion of Science (JSPS), 


\section{T. NUMATA et al.}

by the Foundation for the Promotion of Material Science and Technology of Japan (MST Foundation), and by the Deutsche Forschungsgemeinschaft.

\section{REFERENCES}

1. Bortner $\mathrm{CD}$, Cidlowski JA. The role of apoptotic volume decrease and ionic homeostasis in the activation and repression of apoptosis. Pflugers Arch. 2004:448:313-8

2. Okada Y, Maeno E, Shimizu T, Manabe K, Mori S, Nabekura T. Dual roles of plasmalemmal chloride channels in induction of cell death. Pflugers Arch. 2004;448:287-95

3. Wehner F, Olsen H, Tinel H, Kinne-Saffran E, Kinne RKH. Cell volume regulation: osmolytes, osmolyte transport, and signal transduction. Rev Physiol Biochem Pharmacol. 2003;148:1-80.

4. Wehner F, Bondarava M, ter Veld F, Endl E, Nürnberger HR, Li T. Hypertonicityinduced cation channels. Acta Physiol. 2006;187:21-5.

5. Wehner F. Cell volume-regulated cation channels. Contrib Nephrol. 2006;152:25-53

6. Shimizu T, Wehner F, Okada Y. Inhibition of hypertonicity-induced cation channels sensitizes HeLa cells to shrinkage-induced apoptosis. Cell Physiol Biochem. 2006;18:295-302.

7. Wehner F, Shimizu T, Sabirov R, Okada Y. Hypertonic activation of a nonselective cation conductance in HeLa cells and its contribution to cell volume regulation. FEBS Lett. 2003;551:20-4

8. Caldwell RA, Clemo HF, Baumgarten CM. Using gadolinium to identify stretchactivated channels: technical considerations. Am J Physiol. 2001;275:C619-21.

9. Maruyama T, Kanaji T, Nakade S, Kanno T, Mikoshiba K. 2APB, 2aminoethoxydiphenyl borate, a membrane-penetrable modulator of Ins(1,4,5)P3-induced $\mathrm{Ca}^{2+}$ release. J Biochem (Tokyo). 1997:122:498-505.

10. Delmas P, Wanaverbecq N, Abogadie FC, Mistry M, Brown DA. Signaling microdomains define the specificity of receptor-mediated InsP(3) pathways in neurons. Neuron. 2002;34:209-20.

11. Ma HT, Patterson RL, Van Rossum DB, Birnbaumer L, Mikoshiba K, Gill DL. Requirement of the inositol trisphosphate receptor for activation of storeoperated $\mathrm{Ca}^{2+}$ channels. Science. 2000;287:1647-51.

12. Xu SZ, Zeng F, Boulay G, Grimm C, Harteneck C, Beech DJ. Block of TRPC5 channels by 2-aminoethoxydiphenyl borate: a differential, extracellular and voltage-dependent effect. Br J Pharmacol. 2005;145:405-14.

13. Chung MK, Lee $H$, Mizuno A, Suzuki M, Caterina MJ. 2-aminoethoxydiphenyl borate activates and sensitizes the heat-gated ion channel TRPV3. J Neurosci. 2004;24:5177-82

14. $\mathrm{Hu} \mathrm{HZ}, \mathrm{Gu} Q$, Wang $\mathrm{C}$ et al. 2-aminoethoxydiphenyl borate is a common activator of TRPV1, TRPV2, and TRPV3. J Biol Chem. 2004;279:35741-8.

15. Voets T, Prenen J, Fleig A et al. CaT1 and the calcium release-activated calcium channel manifest distinct pore properties. J Biol Chem. 2001;276:47767-70.

16. Li M, Jiang J, Yue L. Functional characterization of homo- and heteromeric channel kinases TRPM6 and TRPM7. J Gen Physiol. 2006;127:525-37. 